\title{
PERSONALISATION OF LEARNING THROUGH DIGITAL STORYTELLING
}

\author{
Lina Kaminskiene* \\ Nano Khetsuriani**
}

Received: 30.6. 2018

Case study

Accepted: 16. 6. 2019

UDC 37.012:004

DOI https://doi.org/10.30924/mjcmi.24.1.10

\begin{abstract}
The article discusses curriculum management changes while trying to respond to the challenge of learning personalisation in the field of lower-secondary education in Lithuania. The paper investigates what transformations learning personalisation might bring into educational practices and how they change regular curriculum management practices starting from learning environment, new roles of teachers, combining individual and group work in the classroom environment and development of new learning scenarios. This article is based on the findings of a case study of one of the Lithuanian
\end{abstract}

\section{INTRODUCTION}

Today's learners live in a rapidly changing world with opportunities and challenges that are different from the ones many of the previous generations grew up with. A contemporary learner has many educational traits that older educators or educational systems may not be familiar or comfortable with (Cooper, 2012). Today's learners are more demanding and are willing to discover new ways to apply, extend, and expand on existing knowledge. lower secondary schools, when a new learning scenario was implemented creatively applying a digital storytelling method. The research indicates that students' active classroom participation increased, driven by the personalised approach and the use of diverse digital media. The article reveals that learning personalisation supported by technologies brings changes to the classroom management practices and strengthens teacherstudent and peer-to-peer collaboration.

Key words: personalisation, digital storytelling, curriculum.

Responding to these challenges, schools become aware of a more flexible curriculum, which also leads to changes in the role of the teacher and the learner, so the educational goals go beyond the traditional approach to develop subject knowledge. Contemporary schools realise a need to create a new culture of teaching and learning that focuses on how to develop the ability to find, select, evaluate and use the knowledge. Personalised learning is gaining momentum, which brings to the learner's

\footnotetext{
${ }^{*}$ Lina Kaminskienè, PhD, Vytautas Magnus University, Institute of Education, Faculty of Social Sciences, Jonavos str.66-310, Kaunas, Lithuania, Email: lina.kaminskiene@vdu.lt

${ }^{* *}$ Nano Khetsuriani, MA, Vytautas Magnus University, Institute of Education, Faculty of Social Sciences, Jonavos str.66-310, Kaunas, Lithuania, Email: nano.khetsuriani@vdu.lt
} 
initiative and responsibility of learning activities.

The phenomenon of personalisation emphasizes the tendency to meet people's need to take a lead in creating a personalised product or service. In the modern world, personalisation is integrated into various areas: science, business, social services (Klimienè, 2017). Personalised learning is seen as an educational strategy that enables learners to engage in meaningful, unique educational activities and demonstrate their own desired outcomes (Zmuda, Curtis \& Ullman, 2015). In such a learning environment, it is important for a teacher to use relevant contemporary pedagogical strategies enhanced by technologies (Lee at al., 2018). Researchers assume that adequately integrated technologies can help teachers to better monitor learners' learning progress (Lee at al., 2018).

The paper aims to contribute to understanding of how students perceive benefits of personalised learning, which might be realised with the help of technologies and how learning personalisation stimulates changes in curriculum implementation at school. So, in line with these discussions, two key research questions were raised:

1) How does ICT integration in a lower-secondary school classroom can help teachers to create a learner-centred pedagogical approach?

2) How can digital storytelling, as a learner-centred pedagogical tool, enable teachers to enhance personalised learning?

The paper consists of the theoretical part, which presents a critical analysis of scientific literature focused on ICT integration into learning and teaching practices, and contribution of technologies to personalised learning practices. The third part presents the methodology, which was used to conduct the research and its main findings. The paper ends with the discussion of research results, linking them with other studies in the field, and conclusions.

\section{LITERATURE REVIEW}

\subsection{ICT and personalisation of learning}

While promoting educational changes or talking about flexibility and personalisation it is ultimately important to understand the role of digital technologies in this process. ICT can play the role of a catalyst for such educational transformation as technologies promote effective instruction that is more engaging, learner-centred, adaptive to personal learning needs, interdisciplinary and more closely related to real life events. It also encourages the development of higher order cognitive skills and helps to construct knowledge socially. One of the most important roles of ICT in education can be related to learners' increased motivation and engagement levels. ICT fosters experiential acquisition of knowledge and learner-centred pedagogical approach, and thus promote more active learning experiences (Scott, 2015). The increase in digital tools and networked applications transform and shape the current learning landscape and promote change that responds to the demands of 21 st century learners. When used for personalised learning and teaching, ICT can transform the process and organization of education. Digital tools are helping to realise student-centred learning models by allowing learners to take the ownership, accountability and responsibility through the process (Grant and Basye, 2014). Dillon and Humphreys (2005) summarize four key areas vital to establishing personalised learning through digital technologies: 
- Ensuring learner's capacity of making informed and efficient educational decisions.

- Diversifying and recognizing different types of abilities and knowledge while applying ICT.

- Creating and promoting diversity in learning environment through different tools.

- Keeping learners in the focus of whole process.

The goal of personalised learning is also to foster collaboration between learners and the teacher. Through flexibility and adaptability to the learners' needs, personalised learning honours and acknowledges the unique gifts, skills and passions of each learner, as well as their challenges and objections towards learning. Personalised learning approach is based on research on how students can learn most effectively. Effective learning mainly involves active teacher-learner interactions, student-driven participation, access to ICT and flexible curriculum. Together with one-to-one learning, collaborative learning represents another virtue of the personalisation, withtechnologies playing an important role in its implementation. ICT enables students to communicate and work with a range of interactive resources (Redding, 2016).

Facilitating more ICT based activities with powerful and adaptive software can help fuel meaningful instruction. E-libraries, online laboratories, games or online quizzes help learners create and discover more. The excitement of acquiring new knowledge and skills puts students in charge of how they learn (Punie, 2007). While teachers keep them on track and assess their interaction with ICT tools, such environments promote constructivist innovation, which stands for providing more authentic and reflective learning. ICT can be a tool to encourage learning of how to learn rather than learning what to learn, by seeking solutions for particular tasks, engaging students' curiosity and initiation, leading to analytical thinking and encouraging peer-to-peer collaboration. ICT integration in a classroom allows implementing continuous learning processes in different learning contexts and provides on-demand support for students. ICT integration into the educational process minimises "onesize-fits-all" approaches in 21st century learning (Lee and McLoughlin, 2010).

Storytelling as a great tool for sharing and transmitting information, knowledge or values has been known as one of the oldest methods of learning. Storytelling is considered to have great contribution to literacy development by improving learners' language, writing, reading or listening skills. Nowadays, digital stories may help to develop understanding individual experiences and perception of real world among learners (Olivia and Bidarra, 2017). Digital storytelling, as one of the ICT based pedagogical tool, provides student-centred learning strategies based on learners' engagement, reflection, project-based learning, and the effective integration of technology into instruction (McDrury and Alterio, 2000). It enables learners to organize and present their individual stories. As an interactive approach to learning it provides more variation than the traditional methods, it brings more personal essence and improves learners' engagement into the process. Digital storytelling as a pedagogical tool enables teachers to explain certain complex topics in easier manner and create real life or problem-solving situations where learners get actively involved (Gils, 2005).

While developing digital stories, children become authors and co-creators rather 
than passive consumers of information, which creates a more personalised learning content. The benefits of this approach increase when storytelling becomes a collaborative experience. Different digital tools provide interactive systems, which guide learners on a workflow to support the collaboration and at the same time enables teachers to interact effectively within the creation of the plot, characteristics and other media (Richter and Courage, 2017). By increasing peer-to-peer teaching and collaboration, digital storytelling provides pathways towards constructivist approaches in the classroom. As a platform for combining digital tools with new learning and teaching practices, digital storytelling provides additional educational outcomes for learners and supports their motivation or creativity.

In $21^{\text {st }}$ century education, ICTs are greatly contributing to in transforming the process of curriculum management and delivery. As technologies provide kinds of activities that promote higher-order thinking and conceptual understanding of various topics by using a range of software and online resources, they also require teachers to re-think traditional approaches towards curriculum management and pedagogies (Bowes, 2003). This makes technologies essential in new spaces and contexts of interaction between learners and teachers. These new contents and social scenarios give diverse features and new characteristics, which has to be considered while managing curriculum. Current organization of educational content should be committed to a critical integration of ICT and ensuring its beneficial role in learning acquisition (Harman and Brelade, 2015).

Changes and innovations associated with education are having deep impact on understanding of what a curriculum is, how or by whom is it developed and in what ways ICT can help learners develop more critical responses to the information they access while being taught (Caswell and Lamon, 1999). Because of technology integration and many kinds of ICT based activities in the classroom, curriculum is being altered in more dynamic and interactive ways. Students are being encouraged to take charge of the learning process, to engage more independently and remain part of collaborative activities, while working with peers in the classroom or get connected to pupils from schools in other regions and countries outside the classroom. Accordingly, teachers or curriculum developers get more expanded roles and responsibilities while facilitating ICT based learning. They are led to consider curriculum from alternative perspectives - disciplines do no longer have to be kept discrete as ICT supports facilitating more cross-curricular, multidisciplinary approaches (Flanagan and Jacobsen, 2003).

Curriculum, which provides ICT integration and validation, facilitates more high-quality learning as it seeks to provide stronger background to flourish individual capabilities and share student's personal experiences. For these features, new technologies offer diverse benefits, answer variety of learner's needs and increase their interest in the curriculum (Shahmir et al, 2011). Some of the tools and resources are for quick reference, offering teachers insights that they can develop on their own, others might go into more detail, describing how different tools can play important roles at various stages of curriculum management (Haddad, 2003).

Technology extends learning beyond the classroom. In personalised learning, the learner actively implements of his/her learning plan, but he / she needs support to reach the intended learning goal. This can 
be achieved through regular feedback to the learner. The feedback should provide learners with guidance on how to better perform the task, what to take into account when analysing learning resources and developing a product (Lee et al., 2018). Targeted and designed technologies can make an essential contribution to personalising learning by developing personalised learning trajectories, by monitoring individual learning, and by enabling learning experiences in their own way.

\section{METHODOLOGY AND FINDINGS}

\subsection{Gathering data for a case study}

The research is based on a case study. The main focus of a case study is to provide a detailed enquiry, analysis and exploration of particular phenomenon over some period of time, within its context using a variety of data sources (Flyvbjerg, 2006). The target population for this research were 8th grade pupils from the English language classes in one of the Lithuanian lower-secondary schools. This case study is not of a comparative character but is limited to only one group of learners. The data were collected by using several methods: pedagogical action research, written feedbacks from students and focus group interview.

Pedagogical action research was implemented through several steps: 1) introduction of the project applying digital storytelling; 2) grouping based on different types of roles of the learners and discussion of the learning goals; 3) individual work and group brainstorming on the main topic of the project: "My dream school"; 4) development of the storyboard and searching for materials and exploring digital tools; 5) development of digital stories, presentation of the stories and reflection.
After every lesson, students were required to provide written feedback with their ideas and reflections about the process, attitudes towards ICT and their general involvement. Feedbacks were shaped around the conducted lesson and reflected important attitudes, developed skills or demonstrated engagement of learners. Additional data was also collected through focus group interviews. The class was divided into two groups with 7 interviewees in each one. By answering open questions participants were sharing their perceptions, opinions and insight towards the whole learning process they had been through.

The data obtained during the study was analysed using the method of the qualitative content analysis. It is a method that explores the object and the context in order to decipher the meanings of the data (Bitinas, Rupšienè and Žydžiūnaitè, 2008). New qualitative categories of personalised learning through digital storytelling emerged in course of the analysis.

\subsection{Findings of personalised learning experiences}

Results indicate that levels of student engagement fluctuated between moderate and high. The use of digital tools and conducting searches for multimedia resources took these levels to very high and kept learners actively engaged in the process. Research also indicates that learners did more work while working in groups and directly using applications, sharing and exploring digital resources. Collaboration between groups, where different groups helped each other with technical issues, was also indicated. The findings of this research support the idea that digital storytelling can promote greater diversity by personalizing students' experience.

Students' general attitudes towards the development of digital stories demonstrate 
a shared sense of learning uniqueness, which gives opportunity to see how influential this experience was for the participants. This positive attitude was mainly caused by innovative approach of teaching and learning and increased students' engagement, which was one of the main goals while delivering lessons. According to learners' reflections, this type of learning for them firstly becomes associated with fun and engagement, where everyone enjoys participation "You are not limited. I think books are $a$ bit boring and this project was more fun for me" (R1).

Students' level of interaction was from moderate to high, which means that the use of ICT and interactive materials led them to enjoy the learning process. They compare pilot lessons with the traditional ones and support the idea of using ICT in other learning circumstances. Students indicate that this is something new, they have not tried before and highlight the preference of ICT based learning compared to traditional classrooms "I liked this project because it was innovative, new, dreaming and using computers is very creative" (R11).

The use of software and conducting searches for digital media fostered the appeal of and engagement with ICT. In almost all cases students enjoyed using technology, surfing the Internet, and watching other learners' digital stories of. Key learning outcomes identified in the end of the project were mainly connected with developing new ICT skills and literacy, through mastering new tools or exploring Internet for research: "I learnt how to work on ICT and create something online and then share it with others"(R2).

Students also identified the advantage of applying the English language into practice and improving their communication skills. For them, attending the English language workshops or even making a presentation of the digital stories was something new and challenging, which led them to new learning outcomes. "Listen to English language presentations and improve my skills" (R7). This approach encouraged the students to speak more English than Lithuanian and foster confidence, communication and ICT skills.

One of the most important features of this research project was to facilitate learning based on collaboration. The analysis of the interviews shows that teamwork appears to be a great tool for better engagement as it provided platform for learners to share responsibilities and improve sense of "togetherness". As mentioned above, the project had its own framework and criteria, though students were given a freedom to decide on their own stories, organize time between tasks, manage teamwork or etc. "We all were responsible about our own projects and we had to make sure they look good" (R1). This could help them to understand what it looks like to have shared responsibility in contrast to the individual work on a common task: "I liked that we had a freedom to do the project how we want to do" (10). All this leads to an idea of achieving something together, working together. Inthe interviews t "togetherness" was discussed with a lot of passion. This type of team-based work was something new for 8th graders and they definitely enjoyed it. What falls under the idea of "togetherness" is not only achieving something together, but also sharing ideas and helping, supporting each other. "I learnt how to listen to my group mates and work with them" (R12). Students also mention that everybody had an equal opportunity to express their own ideas. This helped them feel confident and comfortable during discussions or brainstorming within their own groups. Likewise, as student profiles were diverse 
in each group, they had an opportunity to understand that every learner has unique capabilities, that they are very different from each other and they all have individual strengths and weaknesses, "we could see that one person know something better than the other" (R10).

During teamwork it was important for each student to understand his or her own personal contribution and role. As the research was focused on a personalised learning approach, "me" has been an important element through the process. From the beginning of the research, each student was assigned a specific role, based on his or her own skills or interests, so that they could apply them into practice. A role-based interaction was not very strictly controlled, and students were given the freedom to act beyond the characteristics of their roles, but they understood the idea that using individual skills and roles can help the whole team to succeed while creating a digital story. Some of them clearly voiced how they used their strengths to contribute to the group results. For example, one of the students was aware of her writing skills which made her take responsibility of preparing the script for the digital story. The technology part was left for other group members. "I like writing a lot, so it was my job to write a story for our school, I wrote it and printed and show to my group and then we start working on it. In ICT I am not that good so other people were doing things in computer and I was just writing it down" (R2). All other interviewees also had an idea of how they personally contributed to achieve the learning goal and at the same time made the team perform better.

Students worked collaboratively and engaged with the digital content and they had their own insights and feedback regarding this particular approach. Everyone was positive was about the experience describing it as very interesting, innovative and different. Using diverse applications, online channels and materials to tell the story enhanced learners' creativity. In the end of the pilot, some of them even mentioned how "proud" they were of what they had created, describing the procedure they had been through. Therefore, we also believe that this type of approach can help students develop self-efficacy and confidence in their individual capabilities: "I do not know how to tell, I think when you put something in a video and share it with others you can be proud of it. I think I am proud of what I did and created this story" (R1). Interviews also indicate that digital storytelling stimulates learners' imagination: "brainstorming, we imagined things, we raised our IQ" (R8).

These discussions show that through collaborative work in groups each student had his or her own personal contribution and voice: "I enjoyed designing buildings and thinking about future" (R13). As one of the goals was to promote personalised learning, the educational process was organized in such a way as to combine individual and group work. Each student had his or her own individual approach towards the development of story and only later they had to find a consensus. As a final result, the students' opinion about the storytelling is positive and is perceived as a creative way to share the ideas and learn new things.

The for the story was "My Dream School" and students actively discussed the concept of dreaming during the interviews as they were considering changes or improvements to introduce into future classrooms. Many students found that by dreaming and by creating stories about their own dreams they expressed personal opinions about how they saw the schools in future, 
what changes they envisioned and how they could be made real. They also compared their own dreams with others and could see differences or similarities. Some of them even mentioned that this topic and dreaming was one of the reasons why they enjoyed participating in this project: "kids should dream, because by dreaming we take our imagination to another level, that's why I enjoyed to work on this project"'(R1). In the end they clearly saw the connection of their stories and their ideas towards future and they felt that one day their stories might become true: "Do you know Julie Vern? When he was a kid he was dreaming about submarines. It was 150 years ago and now submarines really exist and they are nice" (R13).

While interviewing students it was important to get final feedback from their perspective regarding the possible improvements or insights into challenges they faced. One of the issues is the lack of time. As some students have commented, more time assigned for the tasks or in general for the project would allow them to create better stories. Students also discussed how they felt about being in a group and the size of the group. Their preference was expressed from 2 to 3 people, as some of them faced communication problems with peers: "Sometimes it was not easy to contact with all the people in the group" (R1). Students have positioned their ideas regarding making stories on different topics that would suit them personally: "I would do something, which fits me more personally, I think. I like more argument type projects" (R9). This is important to consider because freedom of choice is important in developing learners' motivation to do the task properly. And finally, the students positively responded on the range of tools suggested by the facilitator, so they could design story in a variety of ways.

\section{DISCUSSION}

One of the main purposes of this research was to design a learning strategy based on personalisation approach and integration of ICT which could assist in creating a learner-centred environment.

The main contribution of this particular study can be connected with promoting and integrating unique, personal backgrounds into learning process, encouraging more active engagement of students in the acquisition of knowledge and fostering practical implementation of their existing skills into practice, while working together to achieve the set goals.

Computer technology makes it possible to realize new forms of education, which are associated with connectivity and flexibility. This study hypothesizes that ICT can provide different frameworks for creating new learning context combined with the student-centred instruction, frameworks for more active use of skills, autonomous research of information, sharing and cooperation.

Thus, one of the research questions was to identify if ICT can actually help teachers to create more learner-centred pedagogical approach. The results of the study show that an effective link of personalised learning strategy with technologies help to engage and actively involve students into the learning process. Similar findings have been observed in other studies (Sook, 2004) which recognizes that digital technologies might be an effective learning tool for supporting student's cognitive strategies such as managing his/her own learning, remembering, and thinking as own internal processes.

Through this particular research, digital storytelling workshops were delivered to pilot if this tool can be used for learning 
personalisation. The data received from the students' interviews show that their opinion about this approach is very positive, as they relate the tool with the uniqueness and innovation in learning process. Most of the participants agreed that digital storytelling can be used to allow them to construct their own understanding or experience in a content area, to put them in charge of creating a story, facilitate collaborative activities in which students work together in a small group, promote discussions, help them to develop problem-solving and critical thinking skills. This result is in line with Jakes's (2006) study as it confirmed that digital storytelling helps students explore the meaning of their own experience, give value to it, and communicate the experience on multiple levels to others.

As in this particular case the digital storytelling as a method was implemented in the English language lesson and all workshops were delivered in English, it enabled students to communicate in a foreign language during discussions, information gathering or writing the narratives. Respectively, it led to the results of improved language and communication skills. This research cannot demonstrate if this approach can be successfully implemented in other disciplines, however, McNeil and Robin (2010) suggest that digital storytelling can be used not only in language teaching and learning but also in multiple subject areas including social studies, the arts, and science. This research indicates that applying the method of digital storytelling in the classroom not only supports technical, research or presentation skills but also increases understanding of the subject and potentially might contribute to improvement of academic performance.

One of the important elements of learning personalisation is to empower students to take responsibility of their own learning and to foster collaboration among them. Learners must be active participants in their learning acquisition, which promotes the student-centred and participatory education. Through this case study the social processes like increased communication among classmates improved students' attitude towards executing tasks and working together to achieve the final goal.

This research has demonstrated sense of collaboration in two main aspects: shared responsibility and the idea of togetherness. Concerning the results, each learner mentioned that they all felt part of the group and were willing to engage actively, and when they were demotivated or felt lazy about doing a particular task, the otherss might have encouraged them to stay "awake". These results are evident in the model of the flipped classroom (Bergmann and Sams, 2012) and can be translated to personalize learning environments, which are often used hand-in-hand with the flipped instruction.

The research also points out the importance of the developmental conditions that allow students to generate their own ideas and see the results of their implementation, thus developing their creativity and sense of the ownership of their learning. Technology-enhanced education allows students to experience new tools, play along with them, use language in practice and get benefits from teammates' experience. Digital storytelling supports high level of collaboration via its emphases on collaborative project/works and discussions, personal contribution and research. For the overall project evaluation, students reported that their experiences with digital stories were much more learner-centred than teachercentred, as they had freedom and flexibility of choice. The role of teacher is critical in 
this activity as he or she has to be a facilitator, rather than a direct leader of the process, monitoring that each student is actively involved. As these particular digital storytelling workshops were based on discussions and independent group work, it was possible to foster more learner-centred than teacher-centred learning, which resulted in increased motivation and satisfaction.

The research has limitations as it is based on a case study and the feedback and interviews with students. The research also has no data gathered concerning students' academic achievements. The voice of the professionals, that is teachers, was not considered and this might potentially contribute with additional insights and perceptions of learning personalisation practices. These are potentially new areas for investigation.

\section{CONCLUSIONS}

1. A rapid growth of digital technologies opened up opportunities to develop new pedagogical strategies and implement them in the classroom setting. Technologies by themselves cannot facilitate a learning process unless successfully intertwined with modern pedagogical solutions. Today educational institutions are in the quest of new methods of teaching specifically striving to find methods which could help to achieve a better engagement of learners. Traditional approach of teaching and learning sees a teacher as an organizer of the process, which makes the teacher the only responsible person in the teaching and learning process. A balanced integration of technologies together with personalisation strategies helps teachers to actively engage students in the educational process through multiple activities and dedicate attention to every learner. In this case the role of a teacher is shifting towards an advisor, a manager and a facilitator of the educational process. The learners from this particular case study preferred ICT based lessons, as they enjoyed their unique and innovative character. ICT provided opportunities to access an increased amount of information and use multiple information resources and tools, created a more engaging learning environment in the classroom. Through diversified tools and approaches, working individually and collaboratively, learners found it more interesting to develop new knowledge.

2. Since digital storytelling, as one of the ICT based student-centred approaches, tends to become a significant teaching and learning tool in modern schools it is important to research possible impact of the method on students' learning, engagement or motivation. This research results demonstrate that this approach is a good way to engage students in an innovative way of telling a story in a multimodal way. While working on their digital stories, students learn how to create a story with diverse multimedia tools and resources, which they never used before. Digital storytelling does not only help to increase engagement, but also stimulates a more self-regulative and responsible learning of students as a lot of preparatory work should be done individually before the "pieces" are assembled into a coherent story. After a brief period of instructions, students have become confident and comfortable enough with sharing ideas and writing a story, using new digital platforms and applications while creating digital versions of their initial ideas. Digital storytelling allows combining individual and group work as the students have to find consensus on the fabula which involves a lot of group discussions, stimulates argumentation and balancing of different points of view. The task is to come to a mutual understanding, before delivering a final version of the story. After the digital 
stories were presented, students took time to reflect on their own stories as well as to engage into group reflection on the stories developed by their peers. This leads to

\section{References}

1. Bergmann, J., Sams, A. (2012). Flip Your Classroom: Reach Every Student in Every Class Every Day. Washington DC: International Society for Technology in Education.

2. Bitinas, B., Rupšienè, L. ir Žydžiūnaitè, V. (2008). Kokybinių tyrimų metodologija. Klaipėda: Socialinių mokslų kolegija.

3. Bowes, J. (2003). The Emerging Repertoire Demanded of Teachers of The Future: Surviving The Transition. Paper presented at the IFIP Working Groups 3.1 and 3.3 Working Conference: ICT and the Teacher of the Future. Retrieved from: http://crpit. com/confpapers/CRPITV23Bowes.pdf

4. Caswell, B., Lamon, M. (1999). The Development of Scientific Literacy: The Evolution of Ideas in A Knowledge Building Classroom. London: Paul Chapman Publications.

5. Cooper, T. (2012) Models of youth work: a framework for positive sceptical reflection. Edith Cowan University: ECU Publications

6. Dillon, P., Humphreys, P. (2005). Personalisation and digital technologies. Bristol: Futurelab.

7. Flanagan, L., Jacobsen, M. (2003). Technology leadership for the twenty-first century principal. Journal of Educational Administration,41(2), 124-142.

8. Flyvbjerg, B. (2006)Five Misunderstandings About Case-Study Research. Sage introducing more metacognitive practices into the classroom of a lower-secondary school.

Journals 12(2), 219-245.DOI: $10.1177 / 1077800405284363$

9. Gils, F.V. (2005) Potential Applications of Digital Storytelling in Education. Netherlands: University of Twente.

10. Grant, P., Basye, D. (2014) Personalized Learning: International Society for Technology in Education. Washington, DC: Eugene.

11. Haddad, W. D. (2003). Is instructional technology a must for learning? Oakton: Knowledge Enterprise Inc.

12. Harman C., Brelade S. (2015) Using Human Resources to put Knowledge to Work. Knowledge Management Review 3(1), 26-29.

13. Jakes, D. (2006). Standardsproof your digital storytelling efforts TechLearning. The College of Education and Human Ecology. 47(3), 220-228.

14. DOI: $10.1080 / 00405840802153916$

15. Klimiene, K. (2017). Personalizacijos problematical - reiškiniai, suformavę poreikį, ir jų sąveika su dizaino lauku. Mokslas - Lietuvos ateitis. Vilniaus Gedimino Technikos universitetas, 9(1) 99-110.

16. Lee, M., McLoughlin, C. (2010) Personalized and self-regulated learning in the Web 2.0 era: International exemplars of innovative pedagogy using social software. Australasian Journal of Educational Technology 26(1), 28-43.

17. Lee, D., Huh, Y., Lin, C., Reigeluth, C. (2018). Technology functions for personalised learning in learner-centered 
schools. Educational Technology Research and Development, 66, 1269-1302.

18. McDrury, J., Alterio, M. (2000). Achieving reflective learning using storytelling pathways. Innovations in Education and Teaching International 38(1), 63-73.

19. Olivia, R., Bidarra, J. (2017) Video and storytelling in a digital world: Interactions and narratives in video clips. Academia Publications 32(4), 459-476

20. Punie, Y. (2007) Future Learning Spaces: New ways of learning and new digital skills to learn. Digital Kompetanse, 4(2), 210-225.

21. Redding, S. (2016). Competencies and personalised learning handbook on personalised learning for states, districts, and schools. Philadelphia, PA: Temple University, Center on Innovations in Learning.
22. Richter A., Courage L.M. (2017) Comparing electronic and paper storybooks for pre-schoolers: Attention, engagement, and recall. Journal of Applied Developmental Psychology, 48 (2) 92-102.

23. Robin, B.R., McNeil, S.G (2012) What Educators Should Know about Teaching Digital Storytelling. Digital Education Review, 22, 37-51.

24. Shahmir S. et al. (2011) Role of ICT in the Curriculum Educational System. Procedia Computer Science, 3(11), 623-626.

25. Scott, L. (2015) The Futures of Learning 1: Why must learning content and methods change in the 21 st century? UNESCO Education Research and Foresight, ERF Working Papers Series.

26. Zmuda, A., Curtis, G., Ullman, D. (2015). Learning personalised. The Evolution of the Contemporary Classroom. San Francisco: Jossey-Bass. 


\section{PERSONALIZACIJA UČENJA KROZ DIGITALNO PRIPOVIJEDANJE}

\section{Sažetak}

U ovom se radu raspravlja o kurikularnim promjenama, kao odgovoru na izazov personalizacije učenja u nižem srednjem obrazovanju u Litvi. U radu se raspravlja kakvu bi transformaciju mogla izazvati personalizacija učenja $u$ obrazovnoj praksi te kako se mijenjaju redovite prakse upravljanja kurikulumom, počevši od obrazovnog okruženja, nove uloge nastavnika, kombiniranja individualnog $i$ grupnog rada $u$ razredu, pa do razvoja novih scenarija učenja.
Rad se zasniva na rezultatima studije slučaja niže srednje škole u Litvi, u kojoj je na kreativan način primijenjen novi scenarij učenja, uz pomoć digitalnog pripovijedanja. Istraživanje ukazuje da se povećao angažman učenika za vrijeme sudjelovanja u nastavi, za što se glavni razlog može pronaći u personaliziranom pristupu i korištenju raznolikih digitalnih medija.

Ključne riječi: personalizacija, digitalno pripovijedanje, kurikulum. 